\title{
Effect of high-power diode laser on radical surfaces exposed as dental tubules
}

\section{obliteration: in vitro study}

\author{
Efeito do laser de diodo de alta potência em superfícies radicullares expostas quanto a obliteração \\ dos túbulos dentinários: estudo in vitro
}

Efecto del láser de diodo de alta potencia en superficies varillas expuestas sobre la obliteración de los tubos dentinarios: estudio in vitro

Roberta Janaína Soares Mendes ORCID: https://orcid.org/0000-0002-6266-8810 Faculdade de Odontologia de Piracicaba, Brazil E-mail: robertajsoares@gmail.com

Guilherme Silva Furtado

ORCID: https://orcid.org/0000-0002-8796-1634 Universidade Federal do Maranhão, Brazil E-mail: gfurtado.ufma@gmail.com

Nayanna Matos Sousa ORCID: https://orcid.org/0000-0001-5129-1803 Universidade Federal do Maranhão, Brazil E-mail: nayanna3@gmail.com

Daniele Meira Conde Marques ORCID: https://orcid.org/0000-0001-6378-0858

Universidade Federal do Maranhão, Brazil E-mail: danielemarques.tcc@gmail.com

Rafael Soares Diniz

ORCID: https://orcid.org/0000-0003-2119-584X Universidade CEUMA, Brazil E-mail: rsd_diniz@yahoo.com.br

Letícia Machado Gonçalves ORCID: https://orcid.org/0000-0002-0096-0162 Universidade Federal do Maranhão, Brazil E-mail: lets.mg@gmail.com

Andréa Dias Neves Lago ORCID: https://orcid.org/0000-0003-4303-6399 Universidade Federal do Maranhão, Brazil E-mail: adnlago@gmail.com

\begin{abstract}
The aim of this study was to find adequate parameters of high-power diode laser for obliteration of dental tubules. Newly extracted human teeth (molars) were used for the research that were treated with high-power diode laser and then evaluated by scanning electron microscopy. Roots of 10 healthy teeth were used and prepared in 40 dentin blocks and dividing them into 4 groups: Control Group; G1, G2, G3 (groups treated with high-power diode laser), varying power, energy and application time. The images were evaluated randomly by 2 blinded, calibrated examiners who attributed scores to each image with a level of significance of 5\%. The null hypothesis there was no difference between the groups tested regarding of the obliteration of the dentinal tubules. Considering the scores used for analyzing the SEM images, statistically significant differences were observed between the control and all the experimental groups $(\mathrm{p}<0,05)$. However, the irradiated (experimental) groups showed no statistically significant differences between them, because at all the tested parameters the dentin tubules were shown to be obliterated ( $\mathrm{p}<$ 0.05). The efficacy can be completed in the obliteration of tubules and interruption of fluid movement within the dentin tubules with treatment of the exposed surface with the high-power diode laser; however, the parameters of power and energy lowest showed better results.
\end{abstract}

Keywords: Laser; Dentin; Diode laser; Dental sensitivity.

\section{Resumo}

O objetivo deste estudo foi encontrar parâmetros adequados do laser de diodo de alta potência para obliteração de túbulos dentinários. Dentes humanos (molares) recém-extraídos foram usados para a pesquisa, estes foram tratados com laser de diodo de alta potência e avaliados por microscopia eletrônica de varredura. Foram utilizadas raízes de 10 
dentes hígidos e preparadas em 40 blocos de dentina dividindo-os em 4 grupos: Grupo Controle; G1, G2, G3 (grupos tratados com laser de diodo de alta potência), variando potência, energia e tempo de aplicação. As imagens foram avaliadas aleatoriamente por 2 examinadores calibrados e cegos, que atribuíram pontuação a cada imagem com nível de significância de 5\%. Na hipótese nula não houve diferença entre os grupos testados quanto à obliteração dos túbulos dentinários. Considerando os escores utilizados para a análise das imagens SEM, foram observadas diferenças estatisticamente significativas entre o controle e todos os grupos experimentais $(\mathrm{p}<0,05)$. No entanto, os grupos irradiados (experimentais) não apresentaram diferenças estatisticamente significantes entre si, pois em todos os parâmetros testados os túbulos dentinários se mostraram obliterados ( $\mathrm{p}<0,05)$. A eficácia pode ser completada na obliteração dos túbulos e interrupção do movimento do fluido dentro dos túbulos dentinários com tratamento da superfície exposta com o laser de diodo de alta potência; entretanto, os parâmetros de potência e energia mais baixos apresentaram melhores resultados.

Palavras-chave: Laser; Dentina; Laser de diodo; Sensibilidade dental.

\section{Resumen}

El objetivo de este estudio fue encontrar los parámetros adecuados del láser de diodo de alta potencia para la obliteración de los túbulos dentinarios. Para la investigación se utilizaron dientes humanos recién extraídos (molares), que se trataron con un láser de diodo de alta potencia y se evaluaron mediante microscopía electrónica de barrido. Se utilizaron raíces de 10 dientes sanos y se prepararon en 40 bloques de dentina, dividiéndolos en 4 grupos: Grupo Control; G1, G2, G3 (grupos tratados con láser de diodo de alta potencia), variando potencia, energía y tiempo de aplicación. Las imágenes fueron evaluadas aleatoriamente por 2 examinadores calibrados y cegados, quienes asignaron una puntuación a cada imagen con un nivel de significancia del 5\%. En la hipótesis nula, no hubo diferencia entre los grupos evaluados con respecto a la obliteración de los túbulos dentinarios. Considerando los puntajes utilizados para el análisis de imágenes SEM, se observaron diferencias estadísticamente significativas entre el control $\mathrm{y}$ todos los grupos experimentales ( $\mathrm{p}<0.05$ ). Sin embargo, los grupos irradiados (experimentales) no presentaron diferencias estadísticamente significativas entre ellos, ya que en todos los parámetros probados se obliteraron los túbulos dentinarios ( $\mathrm{p}$ <0.05). La eficacia se puede completar en la obliteración de los túbulos e interrumpiendo el movimiento del fluido dentro de los túbulos dentinarios con el tratamiento de la superficie expuesta con el láser de diodo de alta potencia; sin embargo, los parámetros de menor potencia y energía mostraron mejores resultados.

Palabras clave: Láser; Dentina; Diodo láser; Sensibilidad dental.

\section{Introduction}

Many hypotheses have been proposed for dentin hypersensitivity (DH), attesting the lack of knowledge of professionals in understanding neurophysiological mechanisms, with the one most accepted for DH being Brännström's hydrodynamic theory (Brännström, 1966; Leite, 2017; West et al., 2012). The onset and progression of DH are influenced by the characteristics of the teeth and periodontium, oral environment and external factors. There are numerous risk factors that frequently act in synergy and are influenced by individual susceptibility. DH is a common problem in a large portion of the population that seek, who seek dentists for treatment (Glockner, 2013; Kim \& Park, 2017; Schmidlin \& Sahrmann, 2013). There is a scarcity of epidemiological data about $\mathrm{DH}$, and they vary considerably prevalence rates range from 3 to $98 \%$. This heterogeneity is explained by the difference in selection criteria used for each sample under study, and the diagnostic approaches used (Gillam, 2013; Splieth \& Tachou, 2013).

Evidence-based clinical research, particularly in relation to the pain mechanisms, is scarce and not well understood. The definition of DH has been given as being acute localized pain, with rapid onset, short duration, resulting from exposed dentin, normally in response to chemical, thermal agents, and tactile or osmotic stimuli for which the explanation is not based on dental defects or pathologies (Schmidlin \& Sahrmann, 2013; Kim \& Park, 2017; Splieth \& Tachou, 2013; van Loveren, 2013; Leite, 2017). DH is mainly a diagnosis based on exclusion. Therefore, differential diagnosis plays a central role and a detailed clinical history is indispensable for identification of the etiopathological factors (Glockner, 2013; van Loveren, 2013; N. X. West et al., 2013).

The lasers used for the treatment of DH act both by occlusion of dentinal tubules and blockage of nerve activity (Schmidlin \& Sahrmann, 2013; Leite, 2017; Splieth \& Tachou, 2013). This has been a new treatment concept and has become an area of interest in research in the last few decades. There are two types of lasers: the high power and low-level types that 
present different mechanisms (Leite, 2017; Shiau, 2012). Desensitization appears to depend mainly on the type of laser therapy adopted. As high-power lasers act by means of increase in temperature, forming melting of the dentin surface thereby occluding the tubules (Costa et al., 2016; Osmari et al., 2018; Romano et al., 2011; Sgolastra et al., 2011; Viana et al., 2017). Its use provides the advantage of decontaminating the irradiated surface. The use in the pulsed mode has the advantage of causing cooling of the tissue adjacent to the target tissue (Lopes et al., 2017; Moraschini, 2018; Shiau, 2012).

High power lasers such as Nd:YAG, Er, Cr: YSGG, CO2 have been tested for the main purpose of obliterating dentinal tubules (Costa et al., 2016; Osmari et al., 2018; Romano et al., 2011; Sgolastra et al., 2011; Viana et al., 2017). The desensitizing effect of lasers with medium output power is related to occlusion or narrowing of the dentinal tubules. Therefore, taking the hydrodynamic theory into consideration, this occlusion could mediate the transmission of stimuli from the tooth surface to the pulp (Leite, 2017; Lopes et al., 2017; Shiau, 2012). Only Nd:YAG laser (Al-Saud \& Al-Nahedh, 2012; Cunha et al., 2017) appears to have additional analgesic effect, and it was thus possible to conclude that irradiation could temporarily change the axonal terminals of sensory neurons and block the $\mathrm{C}$ and $\alpha 6$ fibers 14 (Sgolastra et al., 2011; Yilmaz et al., 2011).

Various theories have been suggested with the purpose of explaining the effect of laser irradiation on dentin, as follows: dentinal tubule sealing by fusion and re-crystallization of dentin 12,13, dentin fluid evaporation 14,17, analgesic effect related to depressed synaptic transmission 8 or desensitizing effect related to treatment with Nd:YAG (Al-Saud \& Al-Nahedh, 2012), Er:YAG (Chen et al., 2015), and CO2 lasers (K Ozlem, GM Esad, A Ayse, 2018; Yilmaz et al., 2011).

Based on the suggested theories about the effect of laser irradiation on dentin, the authors thought of an interesting suggestion for the treatment of DH - high power diode laser. The delivery of this laser is similar to that of Nd:YAG laser, fiber optic, and its main difference lies in the mechanism of light generation, thus making it a lower cost laser than Nd:YAG. As active medium, diode laser has a solid semiconductor associated with aluminum, gallium and arsenide. The electrical energy generated is transformed into the laser light beam and can be emitted in pulsed or continuous mode in the form of contact.

Therefore, the aim of the present study was, in an unprecedented manner, to use different treatment protocols for dentin hypersensitivity with high power diode laser (Therapy Surgery, DMC, São Carlos, SP, Brazil) and evaluate the safety of its use on human dentin. The null hypothesis there was no difference between the groups tested regarding of the obliteration of the dentinal tubules.

\section{Materials and Methods}

This is an experimental study, in vitro, of the quantitative type (Koche, 2011; Pereira et al., 2018).

The factor under study was Surface Treatment, at 4 levels, with 3 being experimental and 1 control (Table 1). The experimental units were composed of 40 dentin blocks obtained from human teeth, randomly divided between the dentin surface treatments $(\mathrm{n}=10)$ for the response variable. The response variable Obliteration of Dentinal Tubules was evaluated qualitatively by means of Scanning Electron Microscopy (SEM).

Table 1 - Description of the experimental groups.

\begin{tabular}{|l|l|l|}
\hline & SURFACE TREATMENT & PARAMETERS \\
\hline Control & Without laser irradiation & - \\
\hline 1 & High Power Diode Laser & $\begin{array}{l}700 \mathrm{~mW}, 1,75.105 \mathrm{~W} / \mathrm{cm}^{2}, 30 \mathrm{~s}(2 \text { applications lasting } 15 \mathrm{~s} \text { and } 10 \mathrm{~s} \text { rest } \\
\text { between applications), } 10 \mathrm{~J}, 20 \mathrm{pps} .\end{array}$ \\
\hline 2 & High Power Diode Laser & $\begin{array}{l}500 \mathrm{~mW}, 1,25.105 \mathrm{~W} / \mathrm{cm}^{2}, 30 \mathrm{~s}(2 \text { applications lasting } 15 \mathrm{~s} \text { and } 10 \mathrm{~s} \text { rest } \\
\text { between applications), } 7 \mathrm{~J}, 20 \mathrm{pps} .\end{array}$ \\
\hline 3 & High Power Diode Laser & $\begin{array}{l}500 \mathrm{~mW}, 1,25.105 \mathrm{~W} / \mathrm{cm}^{2}, 45 \mathrm{~s}(3 \text { applications lasting } 15 \mathrm{~s} \text { and } 10 \mathrm{~s} \text { rest } \\
\text { between applications), } 11 \mathrm{~J}, 20 \text { pps. }\end{array}$ \\
\hline
\end{tabular}




\section{Selection and Preparation of Samples}

A total of 10 molars healthy teeth, freshly extracted, obtained from the Human Tooth Bank of the Course in Dentistry at the Federal University of Maranhão were selected after approval from the Research Ethics Committee of the same Institution (Protocol No. 3,107,956). The teeth were immersed in a solution of $100 \mathrm{ml}$ of distilled water to two soup spoons of $2.5 \%$ sodium hypochlorite for 20 minutes and then the samples were stored in distilled water up to the time of use.

The crowns of the teeth were sectioned $1 \mathrm{~mm}$ short of the cement-enamel-junction, using a flexible diamond disc (KG Sorensen, São Paulo, SP, Brazil) (Fig 1a). Subsequently, the root was section in the vestibular-lingual and mesio-distal directions (Figure1b) to guarantee that the root would be divided into 4 fragments (Figure1c). After sectioning, the tooth fragments were embedded in acrylic resin (Fig 1d) to help with handling during the abrading, polishing and chemical etching (17\% EDTA) procedures (Mafra et al., 2017).

Water abrasion papers (3M Wetordry ${ }^{\mathrm{TM}}$, St. Paul, Minnesota, USA) with grits \#220, \#400, \#600, \#1200, \#2000 were used. Each abrasive paper remained for one minute on the Aropol-E (Arotec, Cotia, SP, Brazil) polishing machine at 450 RPM, under cooling, for adequate polishing and exposure of the dentinal tubules (Fig 1e). To simulate hypersensitive dentin, the specimens were immersed in 17\% EDTA solution for $2 \mathrm{~min}$, to remove the smear layer and open the dentin tubules (Kim \& Park, 2017).

\section{Test specimen preparation}

The inorganic matter of all the samples was dissolved with 17\% EDTA solution (EDTA liquid Trisodium Biodinâmica, São Paulo, SP, Brazil) under constant agitation for 5 minutes. Afterwards the samples were randomly divided into the groups according to the surface treatments used, as described in Table 1. And the four fragments of each root remained in the same acrylic block (Figure 1D) and each one received the treatment according to the description in table 1 (figs. $1 \mathrm{~F}$ e $1 \mathrm{G)}$.

\section{Diode Laser}

High power diode laser irradiations (Thera Lase Surgery, DMC, São Carlos, SP, Brazil) were performed in pulsed form, contact mode, perpendicular to the surface (quartz fiber- $300 \mu \mathrm{m}$ ), making scanning movements in the horizontal and vertical directions in accordance with the protocols described in Table 1.

From 2 to 3 irradiations were performed, according to each group, according to the parameters established, with an infrared wavelength, for 15 seconds. An interval of 10 seconds between irradiations was maintained to allow thermal relaxation of the tissue to occur (Aranha \& De Paula Eduardo, 2012; Lopes et al., 2017; Romano et al., 2011; Viana et al., 2017). The use of laser equipment was performed in compliance with all the biosafety rules (ISO 13849-1:2015). 
Figure 1 - Flowchart for making specimens and irradiation with high power Diode Laser.

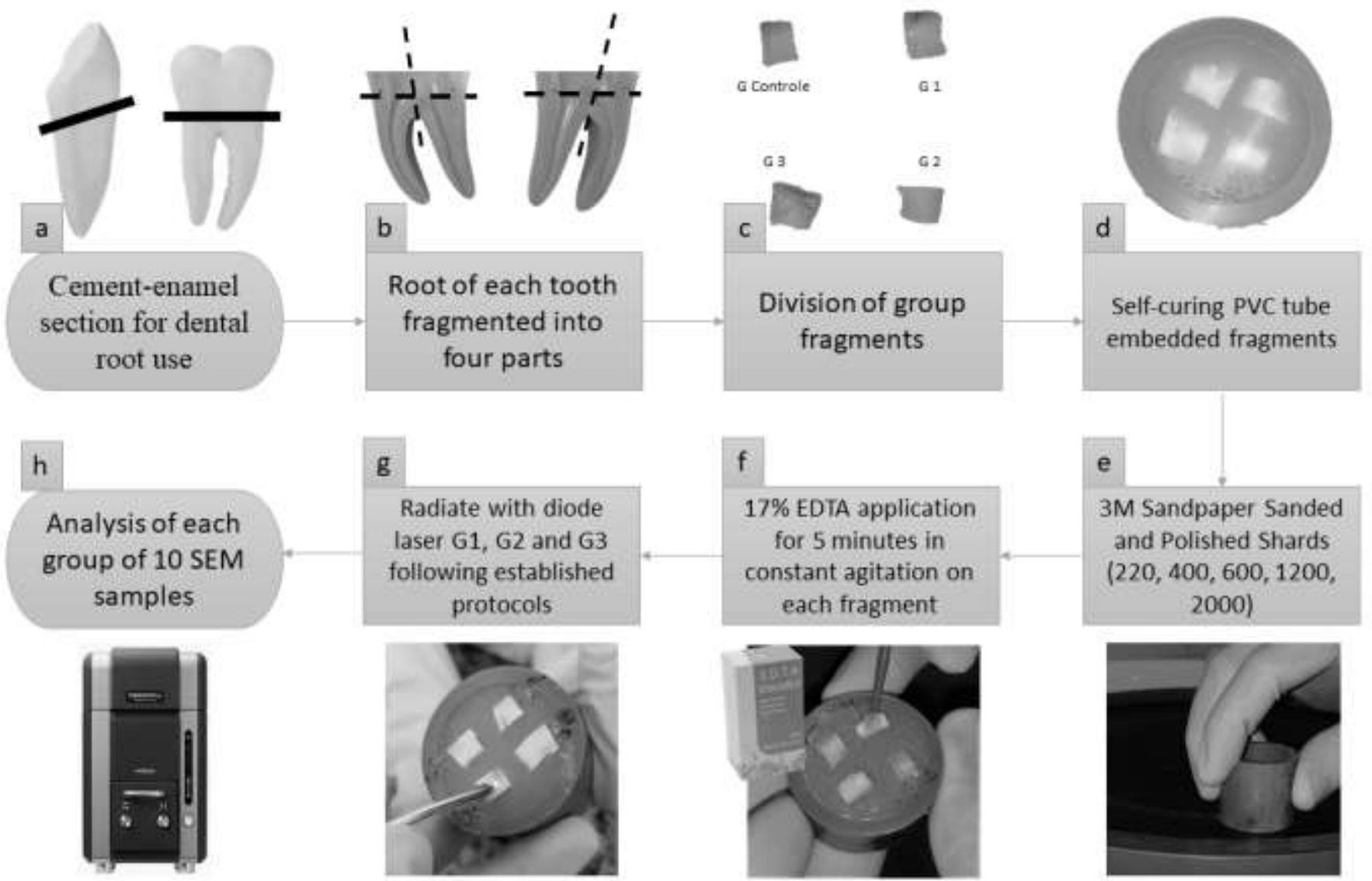

Figure 1 Flow diagram of the research development. $\mathrm{a}$ - Sectioning of the tooth root/crown; $\mathrm{b}-$ Sectioning the root into 4 parts; $\mathrm{c}-$ Tooth Fragments; d - Embedded Fragments; e - Fragments were planned and polished with silicon carbide sandpaper; f - Application of EDTA; g - Irradiation with high power diode laser; $\mathrm{h}$ - SEM. Source: Authors.

\section{Scanning Electron Microscopy}

After EDTA application, all specimens were analyzed by environmental scanning electron microscopy (SEM) to qualitatively verify the number of open dentin tubules. The images were evaluated randomly by 2 blinded, calibrated examiners who attributed scores to each image with a level of significance of 5\%. No sample preparation was required. All specimens were re-evaluated after treatments. In the qualitative assessment, the surface characteristics of micrographs were evaluated and checked the occlusion of the dentinal tubules. After treatment of the tooth surface, the test specimens were submitted to SEM analysis (Hitachi TM 3030, São Paulo, SP, Brazil).

The images obtained at magnifications of 50x, 1000x and 2000x were used for descriptive and qualitative analyses of the samples. To perform these analyses, two blinded, calibrated examiners attributed scores to each image, in accordance with those described in Table 2. The Kappa coefficient was calculated to determine the degree of agreement between the examiners, and a value of 0.9 was obtained.

Table 2 - Table of scores used for analyzing the SEM images

\begin{tabular}{l}
\hline SCORE \\
\hline Score 0 - Completely open tubules \\
Score 1 - Discretely closed tubules \\
Score 2 - Moderately closed tubules \\
Score 3 - Accentuatedly closed tubules \\
\hline
\end{tabular}




\section{Statistical Analysis}

The results obtained were statistically assessed at with the SAS program, adopting a level of significance of 5\%. The Kruskal Wallis non-parametric test was applied to analyze the independent samples, followed by the Dunn method for comparison between groups, with a level of significance of $5 \%$.

\section{Results}

The images were evaluated randomly by 2 blinded, calibrated examiners who attributed scores to each image. After this, the Kruskal Wallis non-parametric test was applied to analyze the independent samples, followed by the Dunn method for comparison between groups, with a level of significance of $5 \%$.

\section{Descriptive Analysis}

Based on the analysis of the images of each experimental group obtained by SEM, adequate and effective exposure of the dentinal tubules was observed in the group used as control, guaranteeing that they were completely free of smear layer. Therefore, the Control Group (Figure 2a) demonstrated that all the fragments were adequately decontaminated and there was adequate exposure of the dentinal tubules. Each sample had its own control group, so that an equal number of exposed dentinal tubules could be obtained per area recorded.

Comparison of the images and data allowed the observation that there was little difference in obliteration regarding the parameters used. Therefore, both Group 1 (Figure 2b), Group 2 (Figure3a) and Group 3 (Figure3b), obtained equal or similar obliteration of the dentinal tubules among the 10 irradiated samples. Despite the excellent result regarding tubular obliteration, small particularities were observed along the irradiated fragments, such as the presence of microcracks and areas of melted, disorganized dentin.

Figure 2 a - Images of each experimental and control group obtained by SEM.

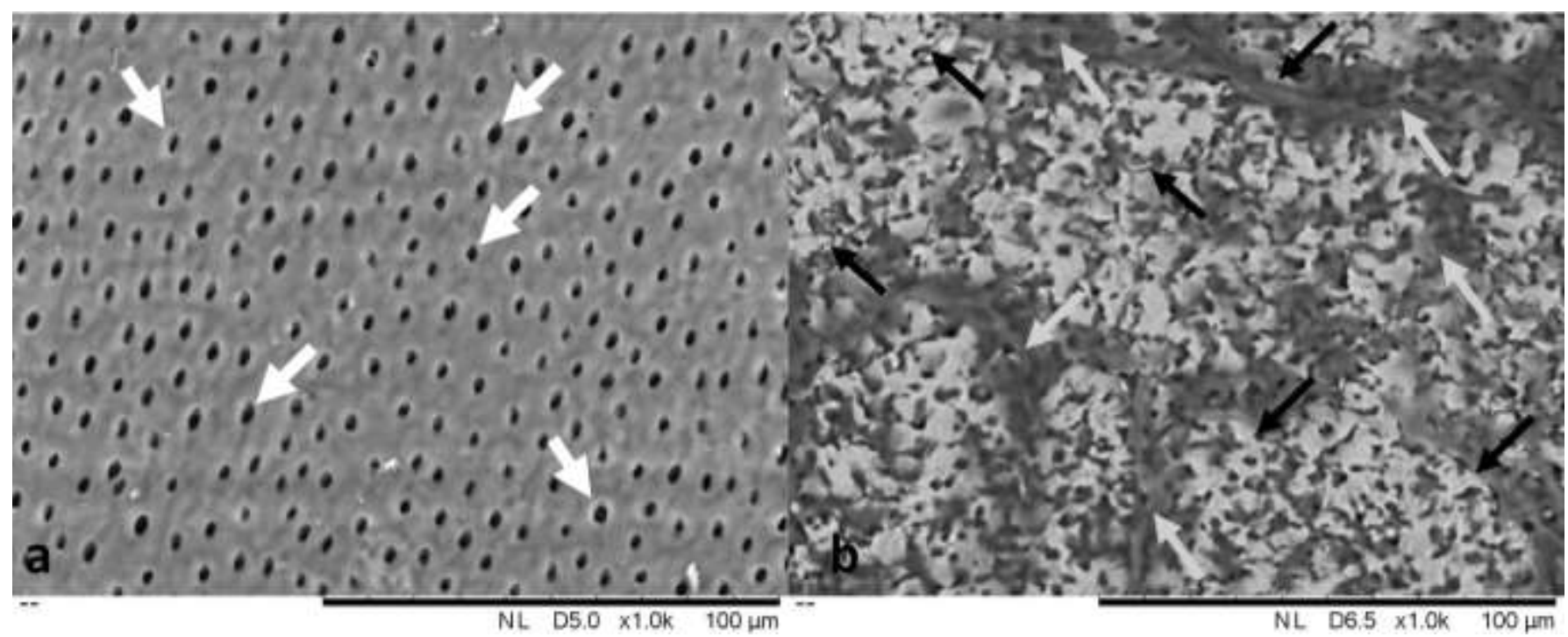

Fig. 2 a - Open dentin tubules, after application of 17\% EDTA (Control Group). b - Group treated with high power diode laser 700 mW (Group 1). White arrows indicate open dentin tubules, black arrows indicate microcracks, and gray arrows indicate melted and disorganized dentin. Source: Authors.

In some samples, the dentinal tubules of Groups 3 and 4 were not adequately obliterated as shown in Figure 3. Therefore it was necessary to observe the possibility of a second application to guarantee adequate sealing of the tubules. Furthermore, along some of the samples, in all the groups extensive presence of microcracks was observed (black arrows). 
Figure 3 - Particularities found in some post-irradiation samples through SEM analysis.

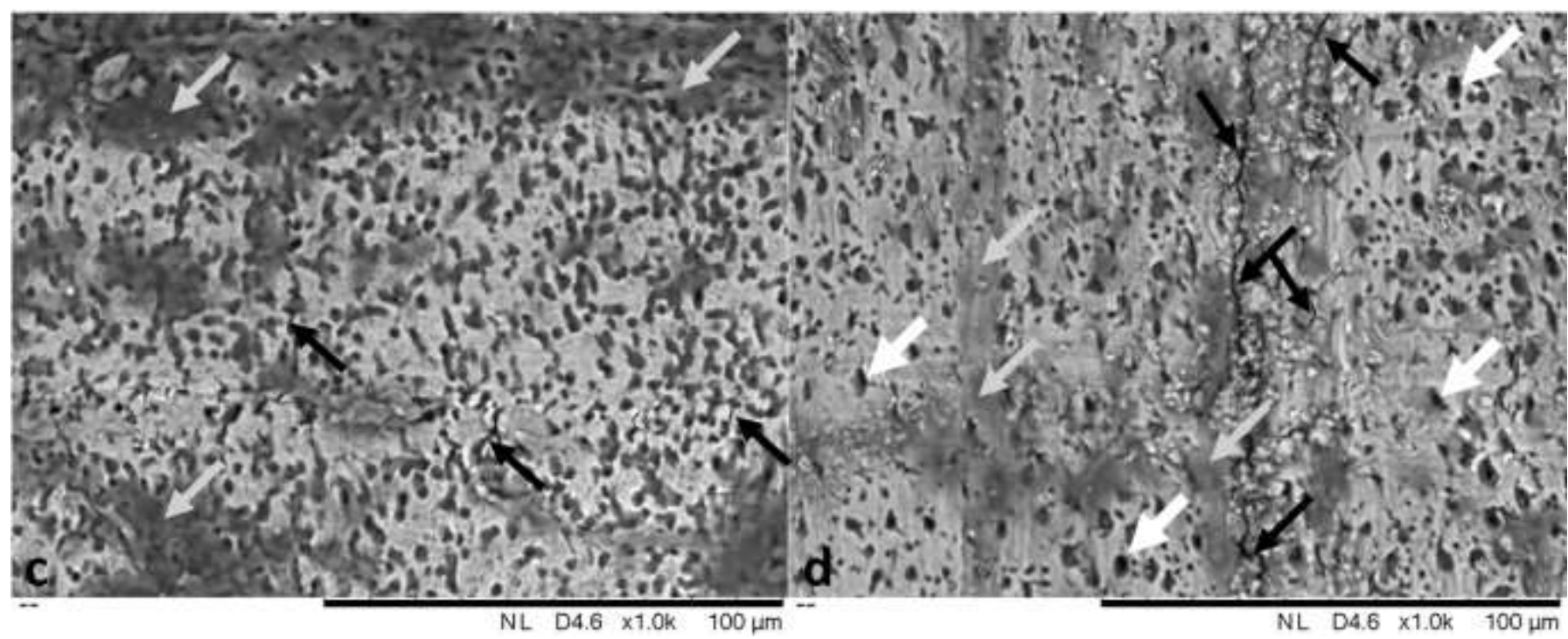

Fig. 3 Groups treated with high power diode laser (a - Group 2, 500mW/7J; b - Group 3, 500mW/11J). White arrows indicate open dentin tubules, black arrows indicate microcracks, and gray arrows indicate melted and disorganized dentin. Source: Authors.

\section{Qualitative Analysis}

Considering the scores used for analyzing the SEM images, statistically significant differences were observed between the control and all the experimental groups (Table 2, p < 0,05). However the irradiated (experimental) groups showed no statistically significant differences between them, because at all the tested parameters the dentin tubules were shown to be obliterated (Table 3, $\mathrm{p}<0.05$ ).

Table 3 - Inter-group analysis by the Dunn test (ns = no significant difference).

\begin{tabular}{cl}
\hline Inter-Group Analysis & Control \\
\hline 1 and 2 & $<0.05$ \\
1 and 3 & $<0.05$ \\
1 and 4 & $<0.05$ \\
2 and 3 & Ns \\
2 and 4 & Ns \\
3 and 4 & Ns \\
\hline
\end{tabular}

Source: Authors.

\section{Discussion}

In this study it was possible to analyze the irradiated dentin surface by means of SEM images, based on scores, and verify that complete or partial obliteration (ranging from a discrete to accentuated level) of the dentinal tubules was found. Therefore, the null hypothesis of this study was accepted, and despite the efficacy relative to obliteration of the dentinal tubules, Groups 1,2 and 3 were observed to present microcracks, generating doubts about the real safety of the parameters used in these groups.

On the other hand, in Group 1 the images showed complete obliteration of the tubules, but with the aspect of an exaggeratedly melted tissue, because it was not possible to observe punctual deposition on the dentinal tubules. Instead, an area 
of dense mass was observed on the dentin surface, suggesting that these parameters may have interfered in the safety of their use, since they could later suggest cause of compromised pulp.

High power diode laser was used in contact with the surface and in these areas a disorganized surface was observed, suggestive of dentin melting, resulting in obliteration of the tubules. In the areas where there was only propagation of the heat, deposition of mineral tissues was observed, resulting in occlusion of the dentinal tubules. These findings agreed with those of Saluja (Saluja et al., 2016) and Gholami (Gholami et al., 2011) who used high power diode laser irradiated in no-contact mode but maintaining a distance of $1 \mathrm{~mm}$ and obtaining a response equal to those reported.

Groups 2 and 3 were those that presented the best aspect of their surfaces, presenting partially obliterated tubules with a discrete reduction in their diameter, without the presence of exaggerated melting. However, in these groups it was possible to verify the presence of microcracks, which were more evident in Group 3. Moreover, it was possible to note that despite the similar parameters studies of Saluja (Saluja et al., 2016) and Gholami (Gholami et al., 2011) that the mode of irrigation was different and needed to be evaluated more carefully. This was because when comparing the SEM images of teeth treated with Nd:YAG laser, sedimentation of minerals in the dentinal tubules was observed in these studies. Whereas, in the teeth used in this research, obliteration by melting of the treated dentin surface was observed. Probably these microcracks may have arisen due to the higher concentration of heat in the irradiated areas the no-contact mode as being the most suitable for this type laser, according Saluja (Saluja et al., 2016) and Gojkov-Vukelic (GojkovVukelic et al., 2016).

Since dentin permeability and hypersensitivity are both reduced when the dentinal tubules are obturated or occluded, techniques and/or agents that effectively occlude the dentinal tubules are extremely important tools in managing hypersensitive dentin (N. X. West et al., 2013). Irradiation with high power laser in the treatment of DH allows sealing of the dentinal tubules, coagulating the proteins of the fluid inside them, diminishing the fluid movement and occluding the tubules. This forms partial melting (fusion and re-solidification) on the exposed dentin and action on the nerve prolongations within it (Aranha \& De Paula Eduardo, 2012; GojkovVukelic et al., 2016; K Ozlem, GM Esad, A Ayse, 2018; Yu \& Chang, 2014).

Another important aspect of the methodology used in this study was with respect to not using a dark photo-absorber before irradiation. This procedure was adopted because both Nd:YAG laser and high power diode laser are better absorbed by the biological chromosomes melanin and hemoglobin. Based on the results of Cunha (Cunha et al., 2017) and Saluja (Saluja et al., 2016) the thermal effects of these lasers on mineral tissue have not yet been well elucidated. Therefore, further studies are necessary without the use of a photoabsorber for standardizing the parameters.

There is a variety of high power lasers available, such as Er:YAG, Er, Cr:YSGG, Nd:YAG, CO2 and diode for this purpose. In the literature, there are effective and safe protocols for the use of Nd:YAG laser to obliterate dentinal tubules (Cunha et al., 2017; Lopes et al., 2017), however, the cost of this equipment is high, unfortunately making it somewhat inaccessible to the majority of professionals. With this in mind, this preliminary study was idealized for the purpose of seeking safe protocols with another time of active medium whose form of delivery was similar to that of Nd:YAG laser - the fiber optic. Therefore, SEM analysis was important for determining what happens to the mineral tissue of the tooth.

In comparison with other lasers, high power diode laser has the advantage of it being possible to transport it (de Araújo et al., 2019), the cost of investment based on this, becomes more accessible to the day-to-day clinical practice of dentists. However, there are few reports in the literature about the use of this laser for the treatment of DH. Therefore, the need to establish safe and effective protocols for obliterating the dental is a reality. This study was therefore conducted with the purpose of seeking safe parameters for the use of high-power diode laser on human tooth fragments with the initial purpose of obliterating the dentinal tubules.

But some questions persist after this study, such as for example: what is the durability of this treatment? Was there structural or chemical change of the irradiated surface? Was the increase in temperature harmful to the pulp? Therefore, further 
studies need to be conducted, seeking to evaluate other parameters, comparing them with (the results of) Groups 2 and 3, and to test other response variables.

\section{Conclusion}

According to the results of the present study, the three high power diode laser parameters tested obliterated the dentinal tubules. However, its long-term effectiveness must be determined through future studies. In addition to in vivo studies to standardize protocols and ensure safety in the use of this Laser for the treatment of this condition.

\section{Acknowledgments}

The authors would like to thank the Fundação de Amparo à Pesquisa e Desenvolvimento Científico do Maranhão FAPEMA (Portuguese acronym for the Maranhão State Research Foundantion) for the financial support provided (Grant $\left.\mathrm{n}^{\circ} 17 / 2014\right)$.

\section{Author Disclosure Statement}

No competing financial interests exit.

\section{References}

Al-Saud, L., \& Al-Nahedh, H. (2012). Occluding Effect of Nd:YAG Laser and Different Dentin Desensitizing Agents on Human Dentinal Tubules In Vitro : A Scanning Electron Microscopy Investigation . Operative Dentistry, 37(4), 340-355. https://doi.org/10.2341/10-188-1

Aranha, A. C. C., \& De Paula Eduardo, C. (2012). Effects of Er:YAG and Er,Cr:YSGG lasers on dentine hypersensitivity. Short-term clinical evaluation. Lasers in Medical Science, 27(4), 813-818. https://doi.org/10.1007/s10103-011-0988-9

Brännström M. (1966). Sensitivity of dentine. Oral Surg Oral Med Oral Pathol., 4, 517-526.

Chen, M. le, Ding, J. feng, He, Y. jiang, Chen, Y., \& Jiang, Q. zhou. (2015). Effect of pretreatment on Er:YAG laser-irradiated dentin. Lasers in Medical Science, 30(2), 753-759. https://doi.org/10.1007/s10103-013-1415-1

Costa, L. M., Cury, M. S., Menezes-Oliveira, M. A. H., Nogueira, R. D., \& Geraldo-Martins, V. R. (2016). A utilização da laserterapia para o tratamento da hipersensibilidade dentinária. Journal of Health Sciences, 18(3), 210. https://doi.org/10.17921/2447-8938.2016v18n3p210-6

Cunha, S. R., Garófalo, S. A., Scaramucci, T., Zezell, D. M., \& Aranha, A. C. C. (2017). The association between Nd:YAG laser and desensitizing dentifrices for the treatment of dentin hypersensitivity. Lasers in Medical Science, 32(4), 873-880. https://doi.org/10.1007/s10103-017-2187-9

de Araújo, J. G. L., Araújo, E. M. dos S., Rodrigues, F. C. N., Paschoal, M. A. B., \& Lago, A. D. N. (2019). High Power Laser and photobiomodulation in oral surgery: Case report. Journal of Lasers in Medical Sciences, 10(1), 75-78. https://doi.org/10.15171/jlms.2019.12

Gholami, G. A., Fekrazad, R., Esmaiel-Nejad, A., \& Kalhori, K. A. (2011). An Evaluation of the Occluding Effects of Er;Cr:YSGG, Nd:YAG, CO 2 and Diode Lasers on Dentinal Tubules: A Scanning Electron Microscope In Vitro Study . Photomedicine and Laser Surgery, 29(2), 115-121. https://doi.org/10.1089/pho.2009.2628

Gillam, D. G. (2013). Current diagnosis of dentin hypersensitivity in the dental office: An overview. Clinical Oral Investigations, 17(SUPPL.1), 21-29. https://doi.org/10.1007/s00784-012-0911-1

Glockner, K. (2013). What are the unmet needs in the dental office/at home to treat dentin hypersensitivity? Clinical Oral Investigations, 17(SUPPL.1), 61-62. https://doi.org/10.1007/s00784-012-0914-y

GojkovVukelic, M., Hadzic, S., Zukanovic, A., Pasic, E., \& Pavlic, V. (2016). Application of Diode Laser in the Treatment of Dentine Hypersensitivity. Medical Archives, 70(6), 466. https://doi.org/10.5455/medarh.2016.70.466-469

Koche, J. C. (2011). Fundamentos de metodologia científica. Vozes.

K Ozlem, GM Esad, A Ayse, U. A. (2018). Efficiency of Lasers and a Desensitizer Agent on Dentin Hypersensitivity Treatment: A Cinical Study. Original Article, 200.137.135.54. https://doi.org/10.4103/njcp.njcp

Kim, J. won, \& Park, J. C. (2017). Dentin hypersensitivity and emerging concepts for treatments. Journal of Oral Biosciences, 59(4), $211-217$. https://doi.org/10.1016/j.job.2017.09.001

Leite, M. F. (2017). Hipersensibilidade dentinária : desafios para diagnóstico e perspectivas de tratamento. Rev Assoc Paul Cir Dent, 71(May), 21-24. 
Lopes, A. O., de Paula Eduardo, C., \& Aranha, A. C. C. (2017). Evaluation of different treatment protocols for dentin hypersensitivity: an 18-month randomized clinical trial. Lasers in Medical Science, 32(5), 1023-1030. https://doi.org/10.1007/s10103-017-2203-0

Mafra, S. C., Girelli, C. F. M., G. Xavier, V. F., Lacerda, M. F. L., Lacerda, G. P., \& Coelho, R. G. (2017). A eficácia da solução de EDTA na remoção de smear layer e sua relação com o tempo de uso: uma revisão integrativa. Revista Da Faculdade de Odontologia - UPF, 22(1), 120-129. https://doi.org/10.5335/rfo.v22i1.6305

Moraschini, V. (2018). Effectiveness for dentin hypersensitivity treatment of non-carious cervical lesions : a meta-analysis. 617-631.

Osmari, D., Fraga, S., de Oliveira Ferreira, A. C., de Paula Eduardo, C., Marquezan, M., da Silveira, B. L., Ferreira, A. C. de O., Eduardo, C. de P., \& Silveira, B. L. da. (2018). In-office Treatments for Dentin Hypersensitivity: A Randomized Split-mouth Clinical Trial. Oral Health \& Preventive Dentistry, 16(2), 125130. https://doi.org/10.3290/j.ohpd.a40299

Pereira, A. S.; Shitsuka, D. M.; Parreira, F. J.; Shitsuka, R. (2018). Metodologia da pesquisa cientifica. UFSM.

Romano, A. C. C. C., Aranha, A. C. C., Da Silveira, B. L., Baldochi, S. L., \& De Paula Eduardo, C. (2011). Evaluation of carbon dioxide laser irradiation associated with calcium hydroxide in the treatment of dentinal hypersensitivity. A preliminary study. Lasers in Medical Science, 26(1), 35-42. https://doi.org/10.1007/s10103-009-0746-4

Saluja, M., Grover, H. S., \& Choudhary, P. (2016). Comparative morphologic evaluation and occluding effectiveness of Nd: YAG, CO2 and diode lasers on exposed human dentinal tubules: An invitro SEM Study. Journal of Clinical and Diagnostic Research, 10(7), ZC66-ZC70. https://doi.org/10.7860/JCDR/2016/18262.8188

Schmidlin, P. R., \& Sahrmann, P. (2013). Current management of dentin hypersensitivity. 17, 0-4. https://doi.org/10.1007/s00784-012-0912-0

Sgolastra, F., Petrucci, A., Gatto, R., \& Monaco, A. (2011). Effectiveness of laser in dentinal hypersensitivity treatment: A systematic review. Journal of Endodontics, 37(3), 297-303. https://doi.org/10.1016/j.joen.2010.11.034

Shiau, H. J. (2012). Dentin hypersensitivity. Journal of Evidence-Based Dental Practice, 12(3 SUPPL.), 220-228. https://doi.org/10.1016/S15323382(12)70043-X

Splieth, C. H., \& Tachou, A. (2013). Epidemiology of dentin hypersensitivity. Clinical Oral Investigations, 17(SUPPL.1), 3-8. https://doi.org/10.1007/s00784-012-0889-8

van Loveren, C. (2013). Exposed cervical dentin and dentin hypersensitivity summary of the discussion and recommendations. Clinical Oral Investigations, 17(SUPPL.1), 73-76. https://doi.org/10.1007/s00784-012-0902-2

Viana, Í. E. L., Aranha, A. C. C., de Paula Eduardo, C., Farias-Neto, A. M., Machado, A. C., de Freitas, P. M., \& Braga, M. M. (2017). Is photobiomodulation (PBM) effective for the treatment of dentin hypersensitivity? A systematic review. Lasers in Medical Science, 33(4), 745-753. https://doi.org/10.1007/s10103017-2403-7

West, N., Seong, J., \& Davies, M. (2012). Dentine hypersensitivity. Erosive Tooth Wear: From Diagnosis to Therapy, 25, 108-122. https://doi.org/10.1159/000360749

West, N. X., Lussi, A., Seong, J., \& Hellwig, E. (2013). Dentin hypersensitivity: pain mechanisms and aetiology of exposed cervical dentin. 17, 9-19. https://doi.org/10.1007/s00784-012-0887-X

Yilmaz, H. G., Kurtulmus-Yilmaz, S., Cengiz, E., Bayindir, H., \& Aykac, Y. (2011). Clinical evaluation of Er,Cr:YSGG and GaAlAs laser therapy for treating dentine hypersensitivity: A randomized controlled clinical trial. Journal of Dentistry, 39(3), 249-254. https://doi.org/10.1016/j.jdent.2011.01.003

Yu, C. H., \& Chang, Y. C. (2014). Clinical efficacy of the Er:YAG laser treatment on hypersensitive dentin. Journal of the Formosan Medical Association, 113(6), 388-391. https://doi.org/10.1016/j.jfma.2013.02.013 